\title{
CHARACTERIZATION AND SPECTRAL MONITORING OF COFFEE LANDS IN BRAZIL
}

\author{
H. M. R. Alves ${ }^{\text {a, }}$, M. M. L. Volpato ${ }^{\text {b }}$, T. G. C. Vieira ${ }^{\text {b }}$, D. A. Maciel ${ }^{\text {b }}$, T. G. Gonçalves ${ }^{\text {b }}$, M. F. Dantas ${ }^{\text {b }}$ \\ ${ }^{a}$ EMBRAPA CAFÉ, Laboratório de Geoprocessamento, Epamig Sul, 37200-000, Lavras, Brasil - helena.alves@embrapa.br \\ ${ }^{\text {b }}$ EPAMIG SUL, Laboratório de Geoprocessamento, 37200-000, Lavras, Brasil - margarete@epamig.ufla.br, (tatianagcvieira, \\ mayarafdantas)@gmail.com, (dmaciel, tgonçalves)@engambiental.ufla.br
}

Commission VIII, WG VIII/8

KEY WORDS: Coffee, vegetation index, NDVI, NDWI, environmental characterization

\begin{abstract}
:
In Brazil, coffee production has great economic and social importance. Despite this fact, there is still a shortage of information regarding its spatial distribution, crop management and environment. The aim of this study was to carry out spectral monitoring of coffee lands and to characterize their environments using geotechnologies. Coffee fields with contiguous areas over $0.01 \mathrm{~km}^{2}$ within a $488.5 \mathrm{~km}^{2}$ region in the south of Minas Gerais state were selected for the study. Spectral data from the sensors OLI/Landsat 8 and the Shuttle Radar Topography Mission from 2014 to 2015 were obtained, as well as information on production areas, surface temperature, vegetation indexes, altitude and slope, were gathered and analyzed. The results indicate that there is great variation in the NDVI and NDWI values, with means ranging from 0.21 to 0.91 (NDVI) and 0.108 to 0.543 (NDWI). The altitude ranged from 803 to $1150 \mathrm{~m}$, and the surface temperature from $20.9^{\circ} \mathrm{C}$ to $27.6^{\circ} \mathrm{C}$. The altitude and the surface temperature distribution patterns were correlated with the vegetation indexes. The slope classes were very homogeneous, predominantly with declivities between 8 to $20 \%$, characterized as wavy relief. This study made possible the characterization and monitoring of coffee lands and its results may be instrumental in decision-making processes related to coffee management.
\end{abstract}

\section{INTRODUCTION}

In Brazil, coffee production has great economic and social importance. However, despite this fact, information on its spatial distribution, management and surrounding environments is still scare. Successful coffee production requires crop monitoring spanning the plants' entire growth process. Usually, this type of monitoring is carried out in the field; it could, however, also be done through satellite images, which can map larger areas at lower costs.

Simple mathematical equations used in digital satellite image processing can highlight the vegetation and analyze reflectance patterns in the leaves and canopy. Among the most commonly used indexes, the Normalized Difference Vegetation Index (NDVI), Enhanced Vegetation Index (EVI) and Normalized Difference Water Index (NDWI) are the most noteworthy. According to Hatfield et. al., (2008), the spectral vegetation index more widely applied in agricultural research is the NDVI. Further, it is also important to understand the relation between climate changes and relief. Volpato et al., (2013) note that the annual variation of NDVI may be a good indicator of plant stress, caused by climate changes. Alves et al., (2011) have also discussed at length the influence of altitude on specialty coffee production in Brazil.

Landsat 8 images, used to obtain spectral and surface temperature data, can be combined with Shuttle Radar Topography Mission (SRTM) digital relief models to subsidize the monitoring of coffee lands. The aim of this work was to apply geotechnologies to the spectral monitoring of coffee lands and to characterize their surrounding environment.

\footnotetext{
"Corresponding author
}

\section{MAIN BODY}

The work was carried out in the municipality of Santo Antonio do Amparo, Minas Gerais state, Brazil. The coffee lands were mapped using Landsat 8, OLI sensor, images with $30 \mathrm{~m}$ spatial resolution, orbit/point 218/75. The images were taken on August 13th, 2015, and were interpreted visually. Only coffee areas over 10 hectares were selected.

To calculate the NDVI (Rouse et al., 1973) and NDWI (Gao, 1996) vegetation indexes, 13 Landsat 8 images (OLI sensor, orbit/point 218/75) from January 2014 to August 2015 were used. All the images were provided by the U.S Geological Survey (USGS, 2015). The atmospheric correction of the images used the 6S algorithm (Vernote et al., 1997; Antunes, 2012). The vegetation spectral indexes of the coffee lands were then calculated and their mean values per polygon were estimated.

In order to calculate the NDVI vegetation indexes (Rouse et al., 1973), surface temperature data were gathered from Landsat 8 images (TIRS sensor, orbit/point 218-75, Band 10 (10.4 - 12.5 $\mu \mathrm{m}), 100 \mathrm{~m}$ spatial resolution). The images were taken on the following dates: 01/02/2014, 08/05/2014, 12/06/2014, $15 / 10 / 2014,18 / 12 / 2014$ e 31/08/2015. They were processed using QGIS 2.12.0 software and the Semi-Automatic Classification Plugin (Congedo; Munafo; Macchi, 2013).

The mean altitude of the coffee lands was estimated using Shuttle Radar Topography Mission (SRTM) images with $30 \mathrm{~m}$ spatial resolution. The slope classes were calculated and defined according to Embrapa 1979: Flat (from 0 to 3\%), Gently undulated (3 to $8 \%$ ), Undulated (8 to $20 \%$ ), Strongly undulated (20 to $45 \%$ ), Hilly (45 to $75 \%$ ) and Steep (above $75 \%$ ). Coffee distribution was assessed according to soil type, based on the digital soil map done at the Center for Agricultural Science of 
the Soils Department of the Federal University of Viçosa (2011).

The municipality of Santo Antonio do Amparo spans an area of $488.5 \mathrm{~km}^{2}$, of which $54 \mathrm{~km}^{2}$ (approximately $11 \%$ ) are occupied by coffee (Coffea arabica L.) The altitude varies between 803 and $1150 \mathrm{~m}$ (Figure 1). Figures 2 and 3 show the spatial distribution of the NDVI and NDWI indexes in the coffee lands. The indexes vary from -1 to 1 . Values closer to 1 indicate full plant metabolic and physiological function and water content in the leaves.

The NDVI mean varied from 0.21 to 0.91 , while the mean NDWI varied between 0.108 and 0.543 . The surface temperature (Figure 4) ranged from $20.9^{\circ} \mathrm{C}$ to $27.6^{\circ} \mathrm{C}$. The higher spectral vegetation indexes occur in the higher altitudes of the central-eastern region of the municipality with, consequently, lower surface temperatures. The quality of the coffee beverage in these areas is higher. Coffee beverage quality depends on the bean's chemical composition, which is determined by genetic factors, crop management and environmental characteristics. Camargo et al., (1992), attempting to characterize the areas with a natural aptitude for coffee production, determine them as the altiplano regions with colder climate (mean annual temperature between $18^{\circ} \mathrm{C}$ and $20^{\circ} \mathrm{C}$ ) and high annual water deficiency during the fruit maturation and harvest periods.

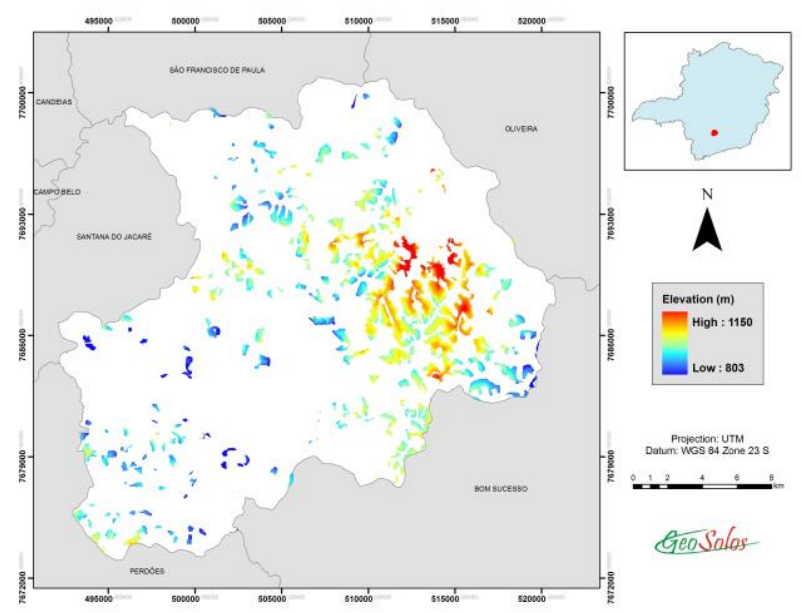

Figure 1. Elevation (m) of coffee fields of Santo Antonio do Amparo, Minas Gerais, Brazil.

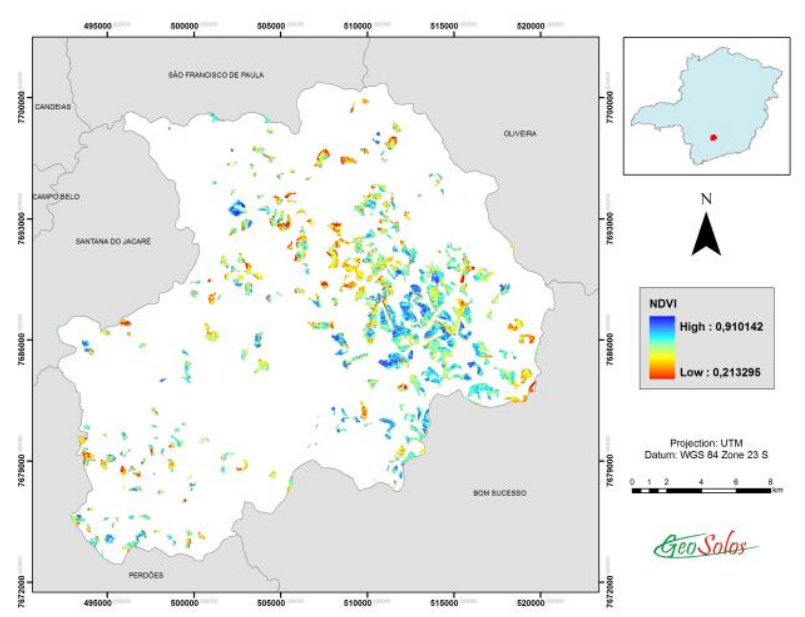

Figure 2. NDVI of coffee fields of Santo Antonio do Amparo, Minas Gerais, Brazil.

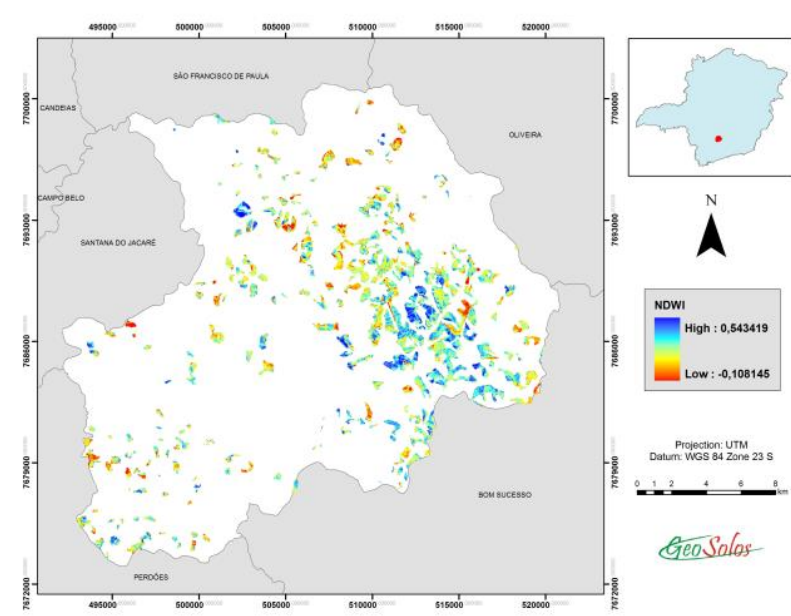

Figure 3. NDWI of coffee fields of Santo Antonio do Amparo, Minas Gerais, Brazil.

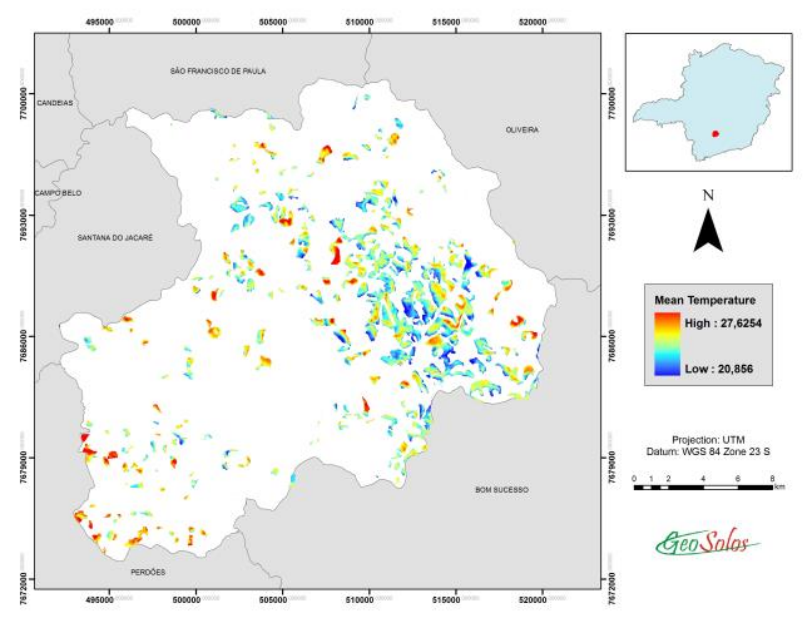

Figure 4. Mean temperature $\left({ }^{\circ} \mathrm{C}\right)$ of coffee fields of Santo Antonio do Amparo, Minas Gerais, Brazil.

The slope classes (Figure 5) were homogenous throughout the area, with a predominance of undulated $(64.4 \%)$ and strongly undulated (17.28\%). The predominant soil classes were RedYellow Latossol (54.08\%) followed by Dark-Red Latossol (36.03\%). The Red-Yellow Latossol occurs in the centraleastern region of the municipality. 


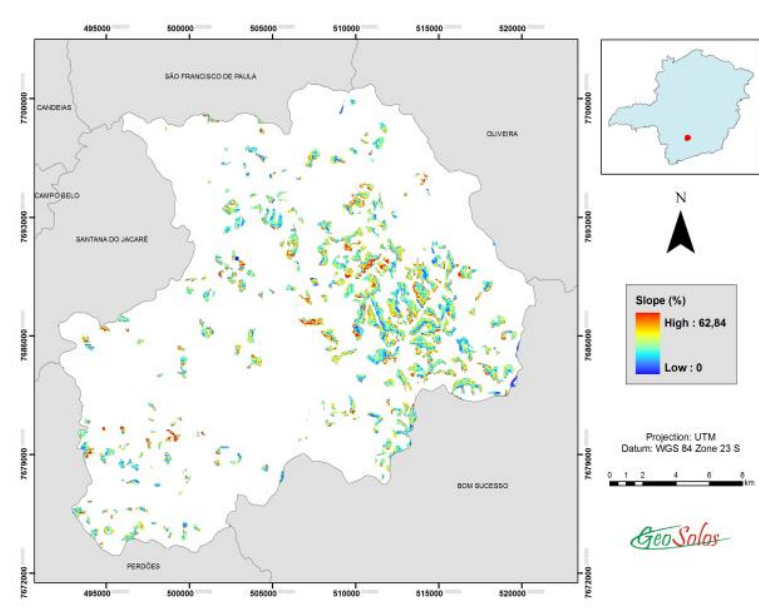

Figure 5. Slope (\%) of coffee fields of Santo Antonio do Amparo, Minas Gerais, Brazil.

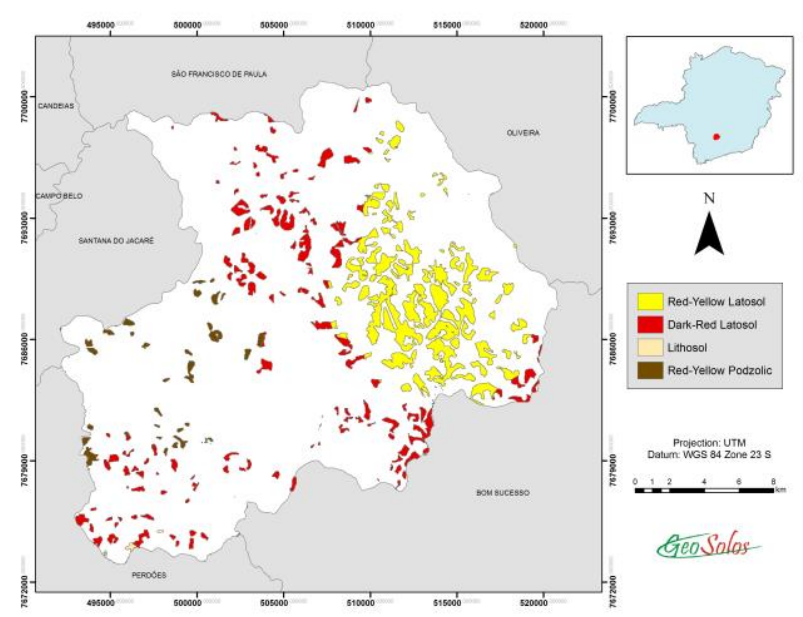

Figure 6. Soil class of coffee fields of Santo Antonio do Amparo, Minas Gerais, Brazil.

\section{CONCLUSIONS}

Using geotechnologies, it was possible to maps the coffee lands of the municipality of Santo Antonio do Amparo, Minas Gerais state, Brazil. The environments that presented greater aptitude for producing quality coffee are concentrated in the higher altitudes, and present lower surface temperature, higher spectral indexes and a predominance of Dark-Red Latossol. This data will be applied to the management of coffee crops in the study area.

\section{ACKNOWLEDGEMENTS}

The authors would like to thank FAPEMIG, Consorcio Pesquisa Cafe and $\mathrm{CNPq}$ for financing the work and for the research fellowships that made it possible.

\section{REFERENCES}

Alves, H. M. R., Volpato, M. M. L., Vieira, T. G. C., Borém, F. M., Barbosa, J. N., 2011. Características ambientais e qualidade da bebida dos cafés do estado de Minas Gerais. Informe Agropecuário, 32(261), pp.18-29.
Antunes, M. A. H., Gleriani, J. M., Debiasi, P., 2012, July. Atmospheric effects on vegetation indices of TM and ETM+ images from a tropical region using the 6S model. In Geoscience and Remote Sensing Symposium (IGARSS), 2012 IEEE International, pp. 6549-6552). IEEE.

Camargo, A. D., Santinato, R., Cortez, J. G., 1992. Aptidão climática para qualidade da bebida nas principais regiões cafeeiras de Arábica no Brasil. In18th Congresso Brasileiro de Pesquisas Cafeeiras, pp. 70-74.

Congedo, L., Macchi, S., 2013. Investigating the relationship between land cover and vulnerability to climate change in Dar es Salaam. Working Paper, Rome: Sapienza University.

EMBRAPA, 1979. Serviço Nacional de Levantamento e Conservação de Solos (SNLCS, 1). Rio de Janeiro, Brazil.

Gao, B. C., 1996. NDWI - A normalized difference water index for remote sensing of vegetation liquid water from space. Remote sensing of environment, 58(3), pp. 257-266.

Hatfield, J. L., Gitelson, A. A., Schepers, J. S., Walthall, C. L., 2008. Application of spectral remote sensing for agronomic decisions. Agronomy Journal, 100 (Supplement 3), pp. S-117.

Rouse Jr, J., Haas, R. H., Schell, J. A., Deering, D. W., 1973. Monitoring vegetation systems in the Great Plains with ERTS. Third ERTS Symposium, NASA SP-351, pp. 309-317.

Vermote, E. F., Tanré, D., Deuzé, J. L., Herman, M., Morcette, J. J., 1997. Second simulation of the satellite signal in the solar spectrum, 6S: An overview. Geoscience and Remote Sensing, IEEE Transactions on, 35(3), pp. 675-686.

UFV, CETEC, UFLA, FEAM, 2010. Mapa de solos do Estado de Minas Gerais. Belo Horizonte: Fundação Estadual do Meio Ambiente, Escala 1:600.000.

U.S. Geological Survey, USGS, 2015. "Landsat 8", United States http://landsat.usgs.gov/landsat8.php (12 out. 2015).

Volpato, M. M. L., Vieira, T. G. C., Alves, H. M. R., Santos, W. J. R., 2013. Imagens do sensor Modis para monitoramento agrometereológico de áreas cafeeiras. Coffee Science, 8(2), pp. 176-182 